\title{
Microbial assemblages on a cold-water coral mound at the SE Rockall Bank (NE Atlantic): interactions with hydrography and topography
}

\author{
J. D. L. van Bleijswijk ${ }^{1, *}$, C. Whalen ${ }^{1, *}$, G. C. A. Duineveld ${ }^{1}$, M. S. S. Lavaleye ${ }^{1}$, H. J. Witte ${ }^{1}$, and F. Mienis ${ }^{1}$ \\ ${ }^{1}$ NIOZ Royal Netherlands Institute for Sea Research, P.O. Box 59, 1790 AB Den Burg, the Netherlands \\ *These authors contributed equally to this work.
}

Correspondence to: F. Mienis (furu.mienis@nioz.nl)

Received: 23 December 2014 - Published in Biogeosciences Discuss.: 22 January 2015

Revised: 2 July 2015 - Accepted: 8 July 2015 - Published: 29 July 2015

\begin{abstract}
This study characterizes the microbial community composition over Haas Mound, one of the most prominent cold-water coral mounds of the Logachev Mound province (Rockall Bank, NE Atlantic). We outline patterns of distribution vertically - from the seafloor to the water column - and laterally - across the mound - and couple these to mound topography and hydrography. Samples of water, sediment and Lophelia pertusa were collected in 2012 and 2013 from locations that were chosen based on high definition video surveys. Temperature and current measurements were obtained at two sites at the summit and foot of Haas Mound to study near-bed hydrodynamic conditions. Overlaying water was collected from depths of $400 \mathrm{~m}$ as well as 5 and $10 \mathrm{~m}$ above the bottom using a CTD/Rosette system. Near-bottom water, sediment and L. pertusa mucus and skeleton samples were obtained with a box corer. Of all these biotopes, Roche GSFLX amplicon sequencing targeting both Bacteria and Archaea was carried out, augmenting our understanding of deep sea microbial consortia. The pattern of similarities between samples, visualized by multi-dimensional scaling (MDS), indicates a strong link between the distribution of microbes and the specific biotopes. The microbial operational taxonomic unit (OTU) diversity was the highest in near-bottom water, which was sampled in the coral framework. For the first time, Thaumarchaeota marine group I (MGI) were found in L. pertusa mucus; Endozoicomonas was detected in skeleton, mucus and near-bottom water, whereas Mycoplasma was only detected in skeleton and near-bottom water, however not in mucus. Analysis of similarities (ANOSIM) indicates that overlaying water is well-mixed at $400 \mathrm{~m}$ depth but less so at
\end{abstract}

5 and $10 \mathrm{~m}$ above the bottom, where the composition of microbial communities differed significantly between summit, slope and off-mound. At all locations, the near-bottom water differed significantly from water at $5 \mathrm{~m}$ above the bottom, illustrating that the near-bottom water in between the coral framework represents a separate microbial habitat. Furthermore, the observed spatial heterogeneity in microbial communities is discussed in relation to environmental conditions.

\section{Introduction}

Numerous mounds composed of mixed sediment and coldwater coral debris line the southeast slope of Rockall Bank between 500 and $1100 \mathrm{~m}$ water depth (Kenyon et al., 2003; van Weering et al., 2003). This so-called Logachev Mound province consists of mounds varying from tens to hundreds of metres in height and several kilometres in length and width (Kenyon et al., 2003). These mounds have been developing since the middle Miocene-early Pliocene, largely as the byproduct of interacting hydrodynamic regimes, coral growth and sedimentation (De Haas et al., 2009; Mienis et al., 2007).

Living coral colonies of Lophelia pertusa and Madrepora oculata inhabit the mound summits and flanks, providing habitat for a wide range of invertebrates and fish (Costello et al., 2005; van Soest et al., 2008). Measurements of currents and temperature around the Logachev Mound province have provided evidence of large regional differences with respect to current strength, temperature fluctuations and organic carbon supply (Mienis et al., 2007). Significant heterogeneity 

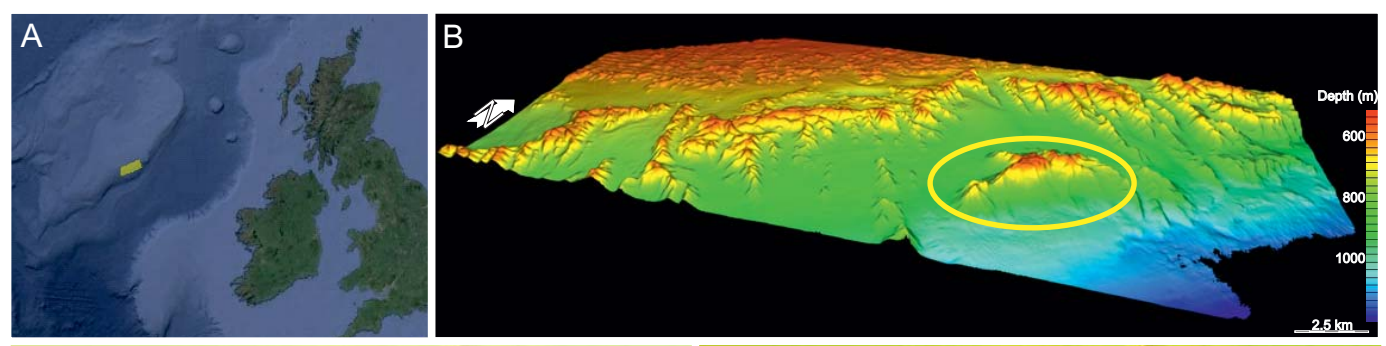

C
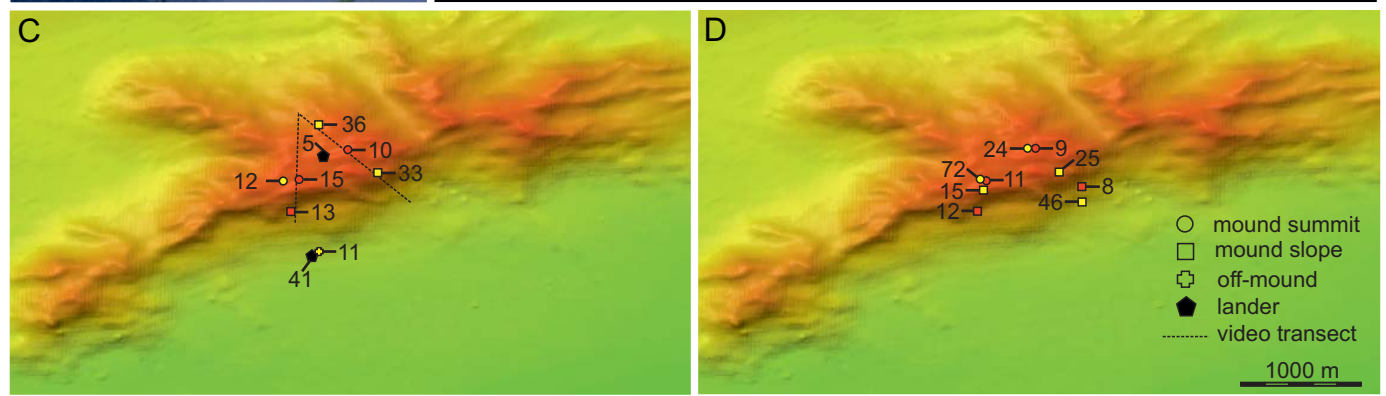

Figure 1. (a) Location of Logachev Mound province (yellow polygon). (b) Multibeam map of Logachev Mounds with Haas Mound encircled. (c) Detail of Haas Mound with lander and CTD stations arranged along two video transects (dotted lines). (d) Detail of Haas Mound with box corer stations indicated. Note CTD02 is not on the map and lies $8 \mathrm{~km}$ SE of CTD10. Red and yellow symbols indicate stations sampled in 2012 and 2013, respectively.

in environmental conditions has also been found within individual mounds, such as between the summit and foot of mound structures (Duineveld et al., 2007). Recent studies on the near-bed hydrodynamic regime in the Logachev Mound province revealed intense mixing on the mounds as a result of internal waves interacting with the topography (Mohn et al., 2014; van Haren et al., 2014). Such mixing provides a supply of food particles, i.e. phytodetritus, and constant refreshment of dissolved oxygen and nutrients (Findlay et al., 2014). The relevance of the hydrodynamic mixing regime for the growth of cold-water coral framework and mounds as a whole is a subject of current studies (F. Mienis, personal communication, 2014).

Other studies have already shown that cold-water coral reefs are hotspots of carbon mineralization (Rovelli et al., 2015; van Oevelen et al., 2009) and metazoan biodiversity and biomass (Biber et al., 2014; Henry and Roberts, 2007), and as such deserve our attention and protection. Whether these reefs are also biodiversity hotspots for microbial communities was qualified as "questionable" based on low bacterial operational taxonomic unit (OTU) numbers in automated ribosomal intergenic spacer analysis (ARISA) profiles (Schöttner et al., 2012). Microbes are crucial for the fitness of tropical corals (Knowlton and Rohwer, 2003; Krediet et al., 2013; Rosenberg et al., 2007). Shifts in the composition or metabolism of shallow-water coral-associated microbial consortia can significantly impair the health of tropical corals by increasing stress and the incidence and prevalence of disease, and by causing mortality (Ainsworth et al., 2010; Dinsdale and Rohwer, 2011; Gilbert et al., 2012; Rohwer and Kelley, 2004).
In deep cold-water coral ecosystems, insight into the distribution and variability of microbial communities is now also progressing. Research has begun to reveal patterns in the composition of microbial communities associated with coldwater corals (Emblem et al., 2012; Galkiewicz et al., 2011; Hansson et al., 2009; Kellogg et al., 2009; Neulinger et al., 2009; Neulinger et al., 2008; Penn et al., 2006; Schöttner et al., 2009; Schöttner et al., 2012; Yakimov et al., 2006) and the ambient environment (Jensen et al., 2012, 2014; Jensen et al., 2008; Schöttner et al., 2012; Templer et al., 2011). Schöttner et al. (2012) concluded that bacteria in coastal cold-water coral reefs are structured based on habitat (coral branch, mucus, water and sediment) and reef location (four reefs located off Norway). Jensen et al. (2014) found bacterial communities to be similar in water sampled proximal $(\sim 1 \mathrm{~m})$ and distal $(30 \mathrm{~m})$ in one reef, whereas in another reef these communities clearly differed.

In the present study, a detailed analysis was made of the composition and distribution of microbial communities across Haas Mound, a deep cold-water coral mound in the NE Atlantic. The main objective of this study is to provide insight into diversity of microbial communities (Bacteria and Archaea) within different biotopes at Haas Mound. Besides the water column, these biotopes included the major surfaces that are in contact with the water, i.e. coral framework, coral mucus and sediment. Our hypotheses are: (1) microbial communities, including Bacteria and Archaea, will be structured based on above mentioned biotopes; (2) within the water column, we expect a reef effect on the microbial community composition at close distance above the reef. 


\section{Materials and methods}

\subsection{Location and sample collection}

Samples were collected during cruises 64PE360 (October 2012) and 64PE377 (October 2013) aboard the RV Pelagia (NIOZ) in the Logachev Mound province on SE Rockall Bank (Fig. 1a). The focus site for this study was Haas Mound, one of the largest and highest carbonate mounds in the Logachev Mound province (Mienis et al., 2006; Fig. 1b). Two transects (Fig. 1c), from the base to the summit of Haas Mound, were surveyed with a tethered HD video camera towed at $2 \mathrm{~m}$ above the bottom (mab). Videos were annotated on board.

Microbial community samples (Table 1) were collected from a range of putative biotopes across Haas Mound that were operationally defined using video information, hydrographic data collected during the 2012-2013 cruises and earlier (e.g. Mienis et al., 2007) and literature on coral microbe interactions (Carlos et al., 2013; Kellogg et al., 2009; Schöttner et al., 2012; Wild et al., 2008). These biotopes were: (i) water well above the mound, i.e. at $400 \mathrm{~m}$ water depth; (ii) water overlaying the coral framework at 5 and $10 \mathrm{mab}$; (iii) near-bottom water; (iv) sediment; (v) uneroded (recently deceased) and eroded $L$. pertusa skeleton; and (vi) L. pertusa mucus.

Box core samples were taken with a $50 \mathrm{~cm}$ diameter, NIOZ designed box corer. This box corer is equipped with a tightly sealing top valve that prevents the leakage and/or exchange of sea water overlaying the sample during ascent, enabling sampling of the near-bottom water once the box corer is on board. A total of nine box cores were collected on the two transects (Table 2, Fig. 1d) and from these, L. pertusa skeleton, mucus and near-bottom water were taken when available. We differentiated between eroded and uneroded skeleton based on discoloration ("white" for uneroded skeleton without biofilm, and "brown" for eroded, older skeleton with biofilm). The water column overlaying Haas Mound was sampled using a rosette sampler equipped with 24 Niskin bottles of $11 \mathrm{~L}$ each, attached to a conductivity-temperaturedepth (CTD) meter. For each CTD drop, water was collected from three different depths: $400 \mathrm{~m}$ water depth and 5 and 10 mab (Table 3, Fig. 1c). Also, a far off-mound station at $1200 \mathrm{~m}$ water depth, situated $10 \mathrm{~km}$ SE from Haas Mound, was sampled with the CTD to determine if water mass characteristics near the mound differ from those off-mound and in deeper water.

Water sampled for microbial DNA analysis was filtered directly on $0.2 \mu \mathrm{m}$ polycarbonate filters (Whatman) using a mild under-pressure of 0.2 bar. From each water depth, three samples of $2 \mathrm{~L}$ were filtered from the same Niskin bottle. The near-bottom water collected from box cores was sampled in a similar way (three samples of $0.5 \mathrm{~L}$ were taken from the same box core). Between two casts, the box corer was thoroughly cleaned and rinsed with seawater. All filters were im- mediately frozen in $6 \mathrm{~mL}$ Pony vials at $-80^{\circ} \mathrm{C}$. Coral mucus as well as skeleton were sampled in at least three replicates per box core (preferably from different colonies) and handled as described in Schöttner et al. (2009), except for skeleton in 2013, when we replaced the scraping technique described by Schöttner et al. (2009) with harvesting $0.5-1 \mathrm{~cm}$ of coral skeleton and directly freezing it at $-80^{\circ} \mathrm{C}$ on board. In the lab, these samples were exposed to liquid nitrogen and homogenized with sterile mortar and pestle.

\subsection{DNA extraction and 16S rRNA amplicon sequencing}

DNA was extracted with Power Soil DNA Extraction Kits (MoBio) according to manufacturer's protocol and extracts were kept frozen at $-20^{\circ} \mathrm{C}$. The concentration of the DNA in the extracts was measured with a F-2500 Fluorescence Spectrofluorometer (Hitachi, Tokyo, Japan) using QUANT-iT ${ }^{\mathrm{TM}}$ PicoGreen ${ }^{\circledR}$ dsDNA kit (Life Technologies, USA). The quality was checked incidentally on $1 \%$ agarose gel. To amplify the V4 region of the $16 \mathrm{~S}$ rDNA, the universal prokaryotic primer sets S-D-Arch-0519-a-S-15 (5-CAGCMGCCGCGGTAA3; Wang et al., 2007) and S-D-Bact-0785-b-A-18 (5TACNVGGGTATCTAATCC-3; Claesson et al., 2009) were used as recommended in Klindworth et al. (2013). The forward primer was extended with a ten-base molecular identifier (MID) barcode to distinguish the samples. Additionally the reverse primer also included a ten-base barcode to distinguish the triplicates. To avoid PCR bias, per DNA extract, two separate $50 \mu \mathrm{L}$ PCR reactions were performed, using one unit of Phusion Taq each (Thermo Scientific) in 1x HighFidelity Phusion polymerase buffer. The volume of template material was adjusted according to the respective DNA concentration to aim for approximately $10 \mathrm{ng}$ genomic DNA per reaction. The PCR was run on an iCycler ${ }^{\mathrm{TM}}$ Thermo Cycler (BioRad, USA). Cycle conditions were as follows: $30 \mathrm{~s}$ at $98^{\circ} \mathrm{C}$, then 30 cycles $\left(10 \mathrm{~s}\right.$ at $98^{\circ} \mathrm{C}, 20 \mathrm{~s}$ at $53^{\circ} \mathrm{C}, 30 \mathrm{~s}$ at $72^{\circ} \mathrm{C}$ ), followed by $7 \mathrm{~min}$ at $72^{\circ} \mathrm{C}$. PCR products were loaded entirely on a $2 \%$ agarose gel pre-stained with SybrSafe and run at $80 \mathrm{~V}$ for $50 \mathrm{~min}$. Blue-light excitation was used when excising the PCR products to avoid UV damage. Duplo PCR products were pooled and purified using the Qiaquick Gel Extraction kit. After fluorimetric quantification as described above, equal amounts (70 ng) of the purified PCR products were pooled (18 samples with their unique forward MID and reverse MID combinations per set). Using a MinElute kit (Qiagen), the volume was adjusted to $25 \mu \mathrm{L}$ with a final concentration of $>50 \mathrm{ng} \mu \mathrm{L}^{-1}$ pooled PCR product per set. In total, seven sets of samples were sent to Macrogen (Seoul, South Korea), each set sequenced using Roche GSFLX instruments and Titanium chemistry on a one-eighth region gasket. 
Table 1. Number of unique samples taken from different biotopes at Haas Mound summit, slope and off mound. Number between brackets is total number of samples analysed, including replicates.

\begin{tabular}{lrrrrr}
\hline Biotope & Sample type & Summit & Slope & Off mound & Total \\
\hline Overlaying water & $400 \mathrm{~m}$ & $4(12)$ & $2(6)$ & $2(6)$ & $8(24)$ \\
& $10 \mathrm{mab}$ & $4(11)$ & $2(6)$ & $2(6)$ & $8(23)$ \\
& $5 \mathrm{mab}$ & $3(9)$ & $2(6)$ & $2(6)$ & $7(21)$ \\
\hline Near-bottom water & w_bc & $4(11)$ & & $1(3)$ & $5(14)$ \\
\hline Skeleton & uneroded & $2(6)$ & $2(6)$ & & $4(12)$ \\
& eroded & $1(3)$ & $1(6)$ & & $2(9)$ \\
\hline Mucus & mucus & $1(3)$ & $1(3)$ & & $2(6)$ \\
\hline Sediment & sediment & $2(6)$ & $2(6)$ & & $4(12)$ \\
\hline
\end{tabular}

\subsection{Sequence processing, taxonomic assignment and diversity analyses}

The sequence library of each sample set was filtered by length and quality, and sorted based on the forward MID using the Ribosomal Database Project (RDP) pipeline initial process (Cole et al., 2014). Only sequences longer than 250 bases with average $Q$ scores above 25 were kept. These sequences were sorted according to the reverse MID tags into the three replicates. In both procedures a maximum of two mismatches in both primers and tags was accepted. At the end of the procedure, each of the seven libraries were split into 18 samples, 6 unique samples each with three replicates. All reads had a similar length of $251 \mathrm{bp}$. Reads were aligned with PyNAST and checked for chimeras using ChimeraSlayer in Qiime. The read files were classified using the SILVAngs web interface (Yilmaz et al., 2014) with default settings ( $>98 \%$ similarity of OTUs and $>93 \%$ classification similarity to closest relative in SILVA database 119).

OTU tables were imported in PRIMERv6 (Clarke and Gorley, 2006). The number of reads per taxonomic unit was normalized per sample to avoid biases caused by differences in sample size. Methodological replicates were pooled. Rarefaction curves and diversity indices were calculated using PRIMERv6 and plotted in R. For a total of 40 samples (pooled from 121 independent methodological replicates: 38 triplos and 2 duplos, namely water of $400 \mathrm{~m}$ at station 36 and near-bottom water at station 72), the average number of reads per sample was 16220 (with standard error 1090). Rarefaction curves of OTUs plotted against reads per sample almost reached a plateau at 14000 reads per sample (Fig. S1 in the Supplement).

Differences in the microbial OTU composition were identified in PRIMERv6 (Clarke and PRIMER, 2006; Clarke, 1993) by analysing Bray-Curtis distance for all pooled samples $(n=40)$ and also for all methodological replicates $(n=121)$. Results were visualized with MDS plots. Distance-based Redundancy Analysis (DBRDA) was done in PRIMERv6 on the samples taken at 5 and 10 mab with seven variables (temperature, salinity, transmission, fluorescence, oxygen, photosynthetically available radiation (PAR), surficial PAR (SPAR)) to explain the variability in microbial community composition within this sample group.

The OTU classification files were processed in Excel and class and genus data were selected for representation to allow easy comparison with other cold-water coral studies (references mentioned in text).

The percentages of reads that were assigned to specific taxonomic units were $99 \%$ to class, $58 \%$ to family and $29 \%$ to genus level. Indicator OTUs, with significant non-random association ( $p<0.0001,9999$ permutations) with one of the five biotopes, were identified with Indicator Species Analysis in $\mathrm{R}$ using the indicspecies package 1.6.7. (De Caceres and Legendre, 2009) with display of both Indicator Values "A" and "B" (Dufrene and Legendre, 1997).

SSU rRNA gene amplicon pyrosequences are available from the European Nucleotide Archive (ENA) via http: //www.ebi.ac.uk/ena/data/view/PRJEB9766. Sample accession numbers are listed in Tables 2 and 3.

\subsection{Near-bed temperature and current measurements}

During the 2012 cruise, temperature and currents were measured on the summit (st5 at $556 \mathrm{~m}, 55^{\circ} 29.677^{\prime} \mathrm{N}$, $15^{\circ} 48.222^{\prime} \mathrm{W}$ ) and at the foot of Haas Mound (st 41 at $861 \mathrm{~m}, 55^{\circ} 28.94^{\prime} \mathrm{N}, 15^{\circ} 48.28^{\prime} \mathrm{W}$ ) with an $\mathrm{FSI}^{\mathrm{TM}} 3 \mathrm{DACM}$ acoustic current meter (Falmouth instruments) with temperature probe, which was attached to a benthic lander at 0.75 mab (Fig. 1c). The duration of each deployment was approximately $48 \mathrm{~h}$.

\section{Results}

\subsection{Haas Mound physical environment and coral cover}

The S slope of Haas Mound is subject to strong daily variations in water mass properties due to internal tidal wave action causing deep, cold water to move up and down the slope 
Table 2. List of box core sampling stations.

\begin{tabular}{|c|c|c|c|c|c|c|c|c|}
\hline Year & Site & $\begin{array}{r}\text { Station } \\
\text { no. }\end{array}$ & Latitude & Longitude & $\begin{array}{r}\text { Depth } \\
(\mathrm{m})\end{array}$ & $\begin{array}{l}\text { Framework } \\
\text { height }(\mathrm{cm})\end{array}$ & Biotope & $\begin{array}{l}\text { Accession } \\
\text { nos. ERS78... }\end{array}$ \\
\hline \multirow[t]{7}{*}{2012} & Mound slope & 15 & $\mathrm{~N} 55^{\circ} 29.45^{\prime}$ & W $15^{\circ} 48.41^{\prime}$ & 528 & $>30$ & Mucus & $3984-86$ \\
\hline & & & & & & & Skeleton-uneroded & $3987-89$ \\
\hline & Summit & 24 & $\mathrm{~N} 55^{\circ} 29.77^{\prime}$ & W $15^{\circ} 48.05^{\prime}$ & 549 & $0-10$ & Near-bottom water & $3990-92$ \\
\hline & Mound slope & 25 & $\mathrm{~N} 55^{\circ} 29.57^{\prime}$ & $\mathrm{W} 15^{\circ} 47.81^{\prime}$ & 568 & $>30$ & Mucus & $3993-95$ \\
\hline & & & & & & & Skeleton-uneroded & 3996-98 \\
\hline & Mound slope & 46 & $\mathrm{~N} 55^{\circ} 29.45^{\prime}$ & W $15^{\circ} 47.64^{\prime}$ & 745 & $10-30$ & Near-bottom water & 3999-4001 \\
\hline & Summit & 72 & $\mathrm{~N} 55^{\circ} 29.51^{\prime}$ & W $15^{\circ} 48.40^{\prime}$ & 562 & $0-10$ & Near-bottom water & 4002-03 \\
\hline \multirow[t]{10}{*}{2013} & Mound slope & 8 & $\mathrm{~N} 55^{\circ} 29.45^{\prime}$ & W $15^{\circ} 47.64^{\prime}$ & 647 & $>30$ & Sediment & 4004-06 \\
\hline & Summit & 9 & N $55^{\circ} 29.77^{\prime}$ & W $15^{\circ} 48.03^{\prime}$ & 547 & $0-10$ & Near-bottom water & 4007-09 \\
\hline & & & & & & & Sediment & $4010-12$ \\
\hline & & & & & & & Skeleton-uneroded & $4013-15$ \\
\hline & & & & & & & Skeleton-eroded & 4016-18 \\
\hline & Summit & 11 & $\mathrm{~N} 55^{\circ} 29.50^{\prime}$ & W $15^{\circ} 48.39^{\prime}$ & 564 & $10-30$ & Near-bottom water & $4019-21$ \\
\hline & & & & & & & Sediment & $4022-24$ \\
\hline & Mound slope & 12 & $\mathrm{~N} 55^{\circ} 29.26^{\prime}$ & W $15^{\circ} 48.45^{\prime}$ & 635 & $>30$ & Sediment & $4025-27$ \\
\hline & & & & & & & Skeleton-uneroded & $4028-30$ \\
\hline & & & & & & & Skeleton-eroded & $4031-36$ \\
\hline
\end{tabular}

Table 3. List of sampling stations of the overlaying water column. mab stands for metres above bottom.

\begin{tabular}{|c|c|c|c|c|c|c|c|c|}
\hline Year & Site & $\begin{array}{c}\text { Station } \\
\text { no. }\end{array}$ & Latitude & Longitude & $\begin{array}{r}\text { Sample } \\
\text { depth }(m)\end{array}$ & $\begin{array}{r}\text { Sample } \\
\text { type }\end{array}$ & $\begin{array}{r}\text { Temperature } \\
\left({ }^{\circ} \mathrm{C}\right)\end{array}$ & $\begin{array}{r}\text { Accession } \\
\text { nos. ERS78... }\end{array}$ \\
\hline \multirow[t]{11}{*}{2012} & Off mound & 11 & $\mathrm{~N} 55^{\circ} 28.92^{\prime}$ & $\mathrm{W} 15^{\circ} 48.33^{\prime}$ & 400 & w_400 m & 9.7 & $4037-39$ \\
\hline & & & & & 895 & $\mathrm{w} \_-10 \mathrm{mab}$ & 6.7 & $4040-42$ \\
\hline & & & & & 907 & w_5 mab & 6.6 & $4043-45$ \\
\hline & Mound summit & 12 & $\mathrm{~N} 55^{\circ} 29.50^{\prime}$ & $\mathrm{W} 15^{\circ} 48.50^{\prime}$ & 400 & $\mathrm{w} \_400 \mathrm{~m}$ & 9.6 & $4046-48$ \\
\hline & & & & & 553 & $\mathrm{w} \_10 \mathrm{mab}$ & 9 & $4049-51$ \\
\hline & & & & & 562 & w_5 mab & 8.9 & $4052-54$ \\
\hline & Mound slope & 33 & N $55^{\circ} 29.57^{\prime}$ & W $15^{\circ} 47.83^{\prime}$ & 390 & w_400m & 10 & $4055-57$ \\
\hline & & & & & 573 & $\mathrm{w} \_10 \mathrm{mab}$ & 8.7 & $4058-60$ \\
\hline & & & & & 578 & w_5 mab & 8.6 & $4061-63$ \\
\hline & Mound slope & 36 & $\mathrm{~N} 55^{\circ} 29.94^{\prime}$ & W $15^{\circ} 48.29^{\prime}$ & 400 & w_400m & 10 & 4064-65 \\
\hline & & & & & 596 & w_5 mab & 8.7 & $4066-68$ \\
\hline \multirow[t]{12}{*}{2013} & Off mound & 2 & $\mathrm{~N} 55^{\circ} 25.95^{\prime}$ & W $15^{\circ} 43.83^{\prime}$ & 400 & $\mathrm{w} \_400 \mathrm{~m}$ & 9.9 & $4069-71$ \\
\hline & & & & & 1192 & $\mathrm{w} \_10 \mathrm{mab}$ & 5.7 & $4072-74$ \\
\hline & & & & & 1200 & w_5 mab & 5.4 & $4075-77$ \\
\hline & Mound summit & 10 & $\mathrm{~N} 55^{\circ} 29.76^{\prime}$ & $\mathrm{W} 15^{\circ} 48.04^{\prime}$ & 400 & $\mathrm{w} \_400 \mathrm{~m}$ & 9.8 & $4078-80$ \\
\hline & & & & & 522 & $\mathrm{w} \_10 \mathrm{mab}$ & 8.8 & $4081-83$ \\
\hline & & & & & 530 & w_5 mab & 8.5 & $4084-86$ \\
\hline & Mound slope & 13 & $\mathrm{~N} 55^{\circ} 29.25^{\prime}$ & W $15^{\circ} 48.44^{\prime}$ & 400 & $\mathrm{w} \_400 \mathrm{~m}$ & 9.7 & $4087-89$ \\
\hline & & & & & 709 & $\mathrm{w} \_10 \mathrm{mab}$ & 9.1 & $4090-92$ \\
\hline & & & & & 718 & w_5 mab & 9.2 & 4093-95 \\
\hline & Mound summit & 15 & $\mathrm{~N} 55^{\circ} 29.50^{\prime}$ & W $15^{\circ} 48.39^{\prime}$ & 400 & $\mathrm{w} \_400 \mathrm{~m}$ & 9.8 & 4096-98 \\
\hline & & & & & 550 & $\mathrm{w} \_10 \mathrm{mab}$ & 9 & 4099-101 \\
\hline & & & & & 555 & w_5 mab & 8.9 & 4102-104 \\
\hline
\end{tabular}


(see details in van Haren et al., 2014). This results in a daily temperature fluctuation at the foot of the mound of $2.5^{\circ} \mathrm{C}$ as measured by the benthic lander. A much smaller temperature fluctuation, i.e. less than $1{ }^{\circ} \mathrm{C}$, was recorded on the summit (Fig. 2a). Temperature, salinity and oxygen profiles measured in 2012 and 2013 are shown for the water column at the off-mound (st2 and 11), mound S slope (st33) and mound summit (st12) sites of Haas Mound (Fig. 2b-d). The temperature of the water column overlaying Haas Mound was around $10^{\circ} \mathrm{C}$ at $400 \mathrm{~m}$ depth and decreased by $1{ }^{\circ} \mathrm{C}$ with every additional $156 \mathrm{~m}$ depth. Salinity was 35.4 at $400 \mathrm{~m}$ depth and decreased slightly with depth. These temperature and salinity values are characteristic of eastern North Atlantic Water. At the deeper off-mound st 11 temperatures decreased to $6.6^{\circ} \mathrm{C}$ at $1000 \mathrm{~m}$ water depth (Fig. 2b), while salinity dropped to 35.2 (Fig. 2c). Both values are indicative of the presence of the Subarctic Intermediate Water (McGrath et al., 2012). The oxygen saturation was around $80 \%$ at $400 \mathrm{~m}$ depth. In the cold water at the far off-mound station (st2) oxygen saturation decreased at $1000 \mathrm{~m}$ to less than $70 \%$ after which an increase was observed at $1200 \mathrm{~m}$ to around $80 \%$ (Fig. 2d). The density of the water was $27.30 \mathrm{~kg} \mathrm{~m}^{-3}$ at $400 \mathrm{~m}$ depth and gradually increased to $27.44 \mathrm{~kg} \mathrm{~m}^{-3}$ at $750 \mathrm{~m}$, which is the depth of the slope of Haas Mound. Below $750 \mathrm{~m}$, density increased to $27.60 \mathrm{~kg} \mathrm{~m}^{-3}$ where deep cold water was encountered. Bottom water temperature at the far off-mound station (st2) was $5.3^{\circ} \mathrm{C}$, while salinity was 35.0 and density $27.7 \mathrm{~kg} \mathrm{~m}^{-3}$.

Video recordings along transects crossing Haas Mound showed large heterogeneity in coral framework distribution. The mound $\mathrm{S}$ slope was characterized by dense framework while the mound summit showed reduced framework alternating with mud patches. At parts of the summit, the coral framework was replaced by a dense cover of large erect sponges (Rosella nodastrella). The foot of the mound S slope ( $\sim 645 \mathrm{~m}$ depth) was sampled by box cores (st46), which revealed a thick layer of coral framework (Fig. 3). Extensive coral framework was also sampled higher up the $\mathrm{S}$ slope near the edge of the summit between 500 and $600 \mathrm{~m}$ depth (Fig. 3a). The density of the coral framework in box core samples taken beyond the edge towards the central part of the summit contained reduced amounts of coral framework, which was in line with video recordings (Fig. 3c, d). One box core station (st24) yielded only mud and small fragments of coral skeleton (Fig. 3c).

\subsection{Microbial communities and diversity in Haas Mound samples}

The number of observed microbial OTUs excluding overall singletons (Table S1 in the Supplement) was the highest in near-bottom water (2415) followed by sediment (2234), skeleton (1878), mucus (1761) and overlaying water (1193). Chao1 indices showed the same trend, decreasing from 3089 in near-bottom water to 1845 in overlaying water (Table S1).
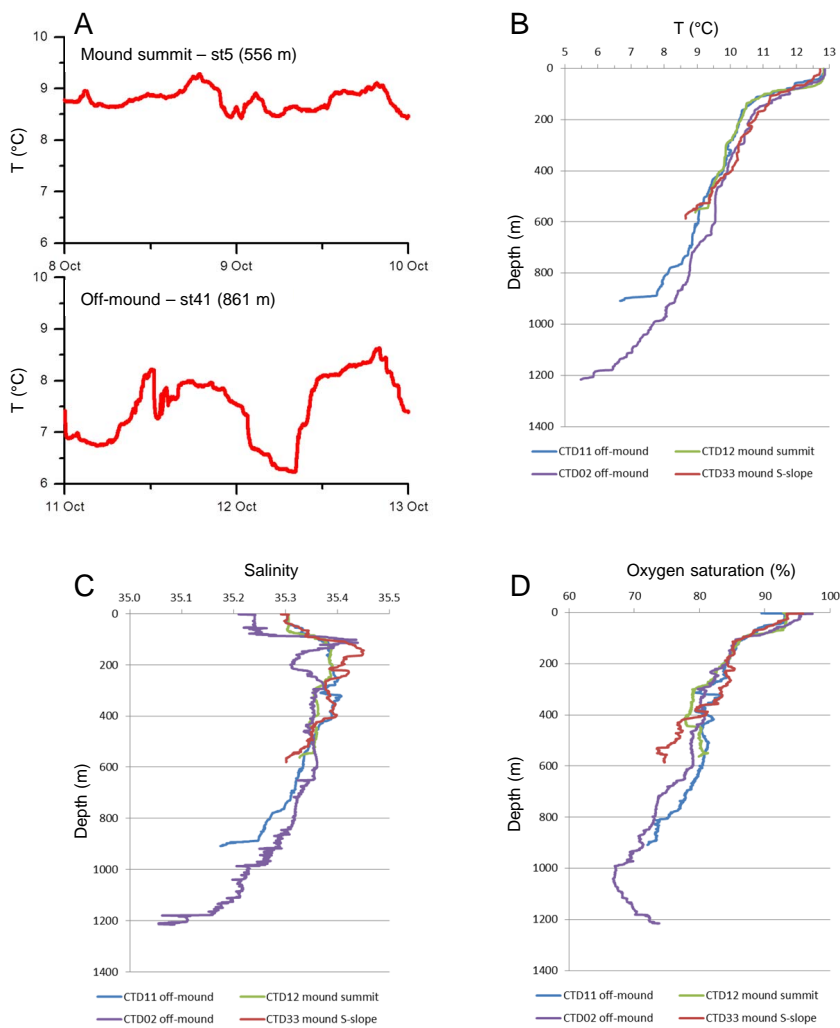

Figure 2. (a) Temperature recorded in situ at the summit and foot of Haas Mound by a current meter on a benthic lander. (b-d) salinity, temperature $\left({ }^{\circ} \mathrm{C}\right)$ and oxygen (\% saturation), respectively, as recorded with the CTD on the slopes and summit of Haas Mound in October 2012 and 2013.

The initial MDS plot of the similarities in OTU composition of the samples immediately showed that the samples of the overlaying water taken at 5 and $10 \mathrm{mab}$ did not differ. This was confirmed by analysis of similarities (ANOSIM) ( $p>0.1 ; 999$ permutations). Hence, these samples were pooled in one category, indicated hereafter as 5 and 10 mab. Subsequent MDS plots were made of the OTU composition in the sample set and these revealed a consistent pattern, i.e. five different clusters which correspond with the biotopes of the samples (Fig. 4, S2). Similar clusters were apparent in plots of microbial classes and genera. Overlaying water at $400 \mathrm{~m}$ was grouped together with water at 5 and $10 \mathrm{mab}$ and formed a tight cluster (Fig. 4). Unexpectedly, near-bottom water, which is in close contact with both reef and sediment, clustered distinctly from overlaying water, sediment, $L$. pertusa skeleton and $L$. pertusa mucus. The following is an account of the composition of the bacterial communities encountered in the samples with emphasis on variation between and within clusters (biotopes) across the mound. 


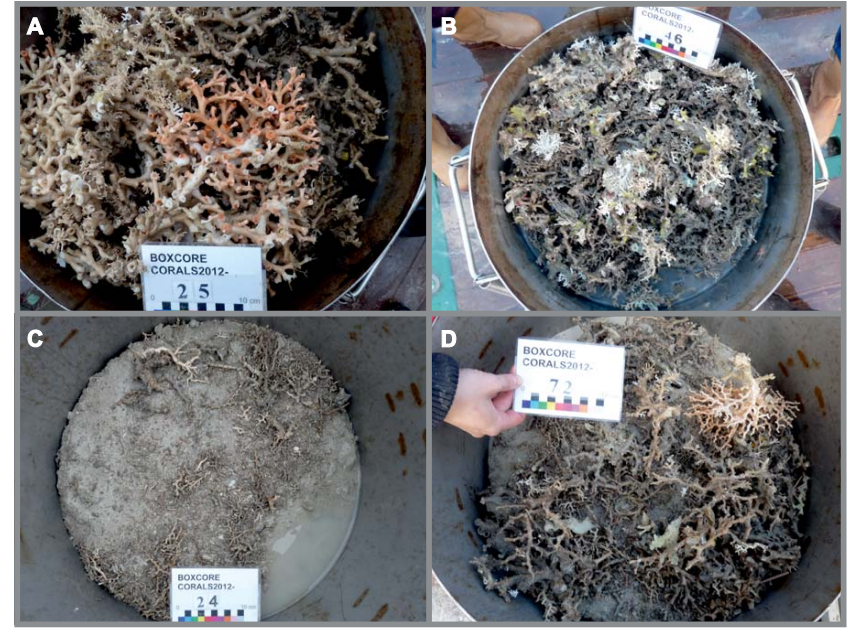

Figure 3. Photographs of box cores taken at the $\mathrm{S}$ slope (a, st 25 and b, st46) and summit (c, st24 and d, st72) of Haas Mound. A clear difference in the amount and height of coral framework was observed.

\subsubsection{Variation between biotopes}

When plotting the microbial community composition of the samples according to class (Fig. 5a), differences become apparent between the biotopes. In near-bottom water, Gammaproteobacteria (22\%) and Thaumarchaeota marine group I (MGI; 22\%) were the most abundant classes followed by Deltaproteobacteria $(11 \%)$ and Alphaproteobacteria $(9 \%)$. Other biotopes shared these four groups, however with different relative abundances (Fig. 5a). Nearbottom water contained relatively high amounts of Halobacteria $(1.2 \%)$, while other biotopes constituted $<0.7 \%$. Sediment and overlaying water both contained relatively less Gammaproteobacteria (14\% in sediment; $18 \%$ in overlaying water) and more Thaumarchaeota MGI (24\% in sediment; $31 \%$ in overlaying water) than near-bottom water. The sediment was characterized by a high percentage of Acidobacteria $(6.0 \%)$ relative to $<4.2 \%$ in other biotopes. In overlaying water we found relatively high amounts of Deferribacteres $(5.9 \%)$ and Thermoplasmata $(6.1 \%)$, while these were found $<2 \%$ in the other biotopes. $L$. pertusa skeleton and mucus contained lower relative amounts of Thaumarchaeota MGI (9 and $11 \%$ respectively) than near-bottom water but still a substantial percentage of their total microbial communities. The mucus was very rich in Gammaproteobacteria (49\%) and also Flavobacteria (4.1\%); levels of Betaproteobacteria $(2.9 \%)$ were relatively high compared to other biotopes. The skeleton was relatively rich in Acidimicrobiia (5.4\%) and Planctomycetia (5.6\%) compared to other biotopes where these bars were below 2.9 and $3.5 \%$, respectively.

Plotting the composition of the samples using a higher taxonomic resolution, i.e. genera, on the basis of their relative abundance (each $>0.5 \%$ of all reads) confirmed the dis-

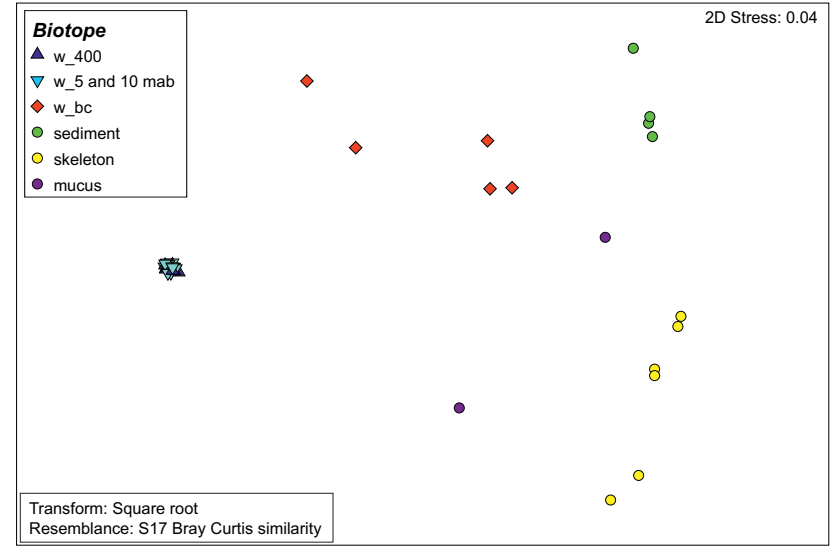

Figure 4. Microbial OTU composition of 40 samples shows clustering according to biotope: overlaying water (w_400 m; w_5 and $10 \mathrm{mab}$ ), near-bottom water (w_bc), sediment, skeleton and mucus. The MDS plot of all 121 samples analysed, including replicates, shows a similar pattern (Fig. S2). The same pattern is apparent for microbial classes and genera (not shown).

tinct signatures of the biotopes. Near-bottom water (Fig. 5b) was distinct from other biotopes due to the relative dominance of Nitrosopumilus (3.2\%), uncultured Xanthomonadales (1,6\%), Defluviicoccus (1.3\%), Marinicella (1.2\%), Brocadiaceae W4 lineage (1.1\%), Nitrosococcus $(0.8 \%)$, Colwellia $(0.6 \%)$ and OM60 clade $(0.6 \%)$. Overlaying water was relatively rich in Salinisphaeraceae ZD0417 marine group $(1.9 \%)$ and Rhodospirillaceae AEGEAN-169 marine group $(2.0 \%)$ compared to other biotopes where proportions were $<0.4 \%$ and $<0.3 \%$, respectively. Pseudospirillum, Nitrosopumilus, Nitrospina and the Flavobacteriaceae NS5 group each contributed between 0.5 and $1.1 \%$ to the microbial community of the overlaying water. A comparison of the relative abundance of the class Thaumarchaeota MGI with the abundance of the genus Nitrosopumilus indicates that the latter contributed $\sim 2.5 \%$ to this class in overlaying water $(\sim 17 \%$ in near-bottom water and sediment and $\sim 35 \%$ in skeleton and mucus), meaning that other, unknown genera contributed $97 \%$ to the Thaumarchaeota class in overlaying water. The sediment was relatively rich in uncultured Xanthomonadales $(2.9 \%)$ and $\mathrm{Ni}$ trosococcus $(1.5 \%)$ in comparison to other biotopes where percentages were $<1.7 \%$ and $<0.8 \%$, respectively. Skeleton samples contained relatively high percentages $(>1 \%)$ of Nitrosomonas, Nitrospira, Entotheonella, Granulosicoccus, Rhodobium, Blastopirellula and Pseudahrensia, while the proportions from other biotopes were $<0.5 \%$. Mucus samples contained large amounts of Alteromonadaceae BD17 clade (22\%, SE 9\%) and Acinetobacter (9\%, SE 9\%), with high variability between the samples. Aquabacterium (1.9\%), Endozoicomonas (1.5\%), Polaribacter (1.3\%) and Pseudomonas (1.0\%) were the most apparent genera in mucus. Mycoplasma was not found in mucus but this genus was 


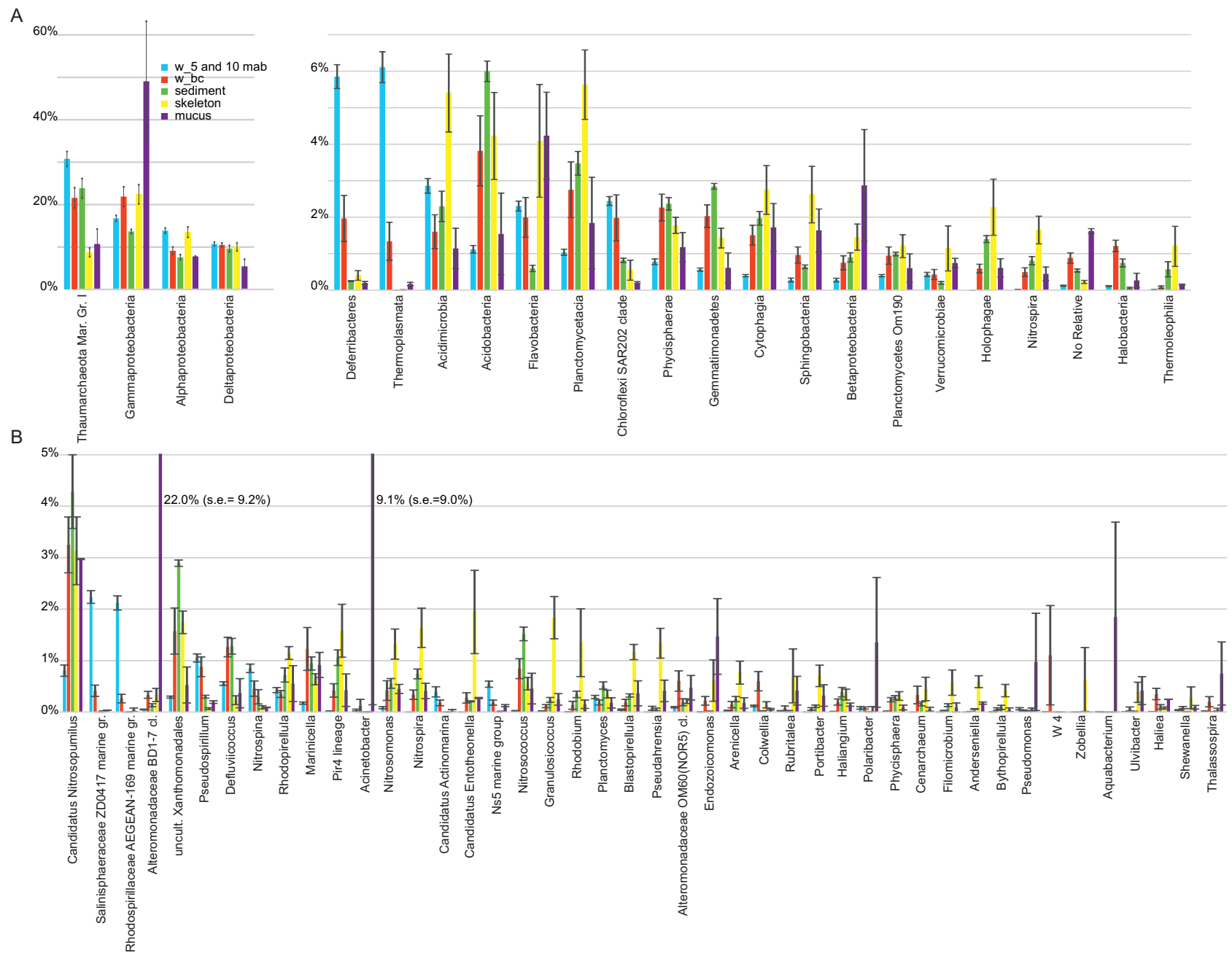

Figure 5. Microbial community composition of five biotopes sampled at Haas Mound. $N$ is the number of unique samples per biotope where the letter a shows the total number of samples, including replicates. (a) The most abundant ( $>1 \%$ of total reads) classes for water at 5 and $10 \mathrm{mab}(n=15$, a45), near-bottom water w_bc $(n=5$, a14), sediment $(n=4$, a12), skeleton $(n=6$, a21) and mucus $(n=2$, a6). (b) The most abundant $(>0.5 \%$ of total reads) genera for water at 5 and 10 mab, near-bottom water w_bc, sediment, skeleton and mucus. Values are plotted as percentage, with standard error.

present in low percentages in skeleton $(0.03 \%)$ and nearbottom water $(0.01 \%)$.

Specific indicators, i.e. taxa that showed a significant nonrandom association to a specific biotope, were found for all biotopes (Table S1). The number of strong indicators (i.e. given the indicator is present, the probability that the sample belongs to a certain biotope $>0.85$ ) was the highest in nearbottom water and mucus ( 8 and 12 strong indicators, respectively) and low in overlaying water, sediment and skeleton (4, 0 , and 0 strong indicators, respectively). Brocadiaceae W4 and Dehalococcoidia were the most abundant strong indicators in near-bottom water whereas SAR11 clade Deep 1 and Oceanospirillales ZD0405 were typical for overlaying water. The mucus was characterized by Alteromonadaceae BD1-7 and Acinetobacter.

\subsubsection{Variation within biotopes}

Within clusters belonging to two of the five main biotopes, patterns were present that could be related to additional factors (Fig. 7 and 8). Within the overlaying water cluster, depth category ( $400 \mathrm{~m}$ versus 5 and $10 \mathrm{mab}$ ) and year (2012 versus 2013) were discriminating factors as illustrated in the MDS plot (Fig. 7) and determined by ANOSIM ( $p<0.01$ and $p<0.0001$, respectively, 9999 permutations). Within the group of samples taken at 5 and $10 \mathrm{mab}$, three clusters were recognized according to their geographic position. Samples taken on Haas Mound summit clearly differed $(p<0.001$, 9999 permutations) from samples taken at deeper locations on Haas Mound slope and from samples taken off-mound. Deeper samples contained relatively more Thaumarchaeota Marine Group I (Fig. 6a). Opposite trends (decreasing with 
depth) were detected in the classes Gammaproteobacteria, Alphaproteobacteria and Acidimicrobiia (Fig. 6a) and in the genera Pseudospirillum, Nitrospina and NS5 marine group (Fig. 6b). A small but significant interannual effect was present in the water samples taken at $400 \mathrm{~m}$ and at 5 and 10 mab on Haas Mound, however the year effect was not shown in off-mound samples taken at 5 and 10 mab (Fig. 7). Distance-based redundancy analyses indicated that depthcorrelated variables, i.e. temperature, salinity and density, only explained $17 \%$ of the total variation in microbial community composition of overlaying water at 5 and 10 mab. Turbidity of the water explained an additional $14 \%$ and was correlated with year $(r=-0.97)$.

Within the cluster of skeleton samples, uneroded dead coral skeleton hosted a distinct microbial community from eroded dead skeleton (Fig. 8). Uneroded dead skeleton contained more of the classes Gammaproteobacteria and Sphingobacteria (Fig. 6c) whereas eroded skeleton communities contained relatively more Acidobacteria and Planctomycetia (Fig. 6c). On the genus level, uneroded dead skeleton contained more Nitrosopumilus, uncultured Xanthomonadales, Blastopirellula and Pseudahrensia among others, whereas eroded skeleton contained more Rhodopirellula, Pir 4 lineage and Rhodobium (Fig. 6d). No patterns were found within the clusters of near-bottom water, sediment and $L$. pertusa mucus samples.

\section{Discussion}

\subsection{Microbial communities and hydrography}

The temperature measurements made during this study on Haas Mound support previous observations and models, showing that the $\mathrm{S}$ slope of Haas Mound is subject to intensified mixing caused by internal waves (Mohn et al., 2014; van Haren et al., 2014). By contrast, conditions on the summit of the mound are less dynamic because the internal wave height is less than the mound height and the deep cold water does not reach the summit, but flushes around the slopes of the mound (van Haren et al., 2014). The distribution of dense, live coral framework on the slope seems to match with the degree of mixing, as framework was found to be less abundant on the summit (Fig. 3). This pattern suggests that mixing is important, for supplying food particles, i.e. phytodetritus (Duineveld et al., 2007), to the living corals, as well as transporting dissolved nutrients, organic carbon, $\mathrm{CO}_{2}$ and $\mathrm{O}_{2}$, as is observed near tropical shallow water reefs (Genin et al., 2002; Reidenbach et al., 2006).

The distribution of microbial communities across Haas Mound, in some aspects, also reflects local hydrodynamic patterns, though small interannual effects are apparent. Microbial communities in the overlaying water at $400 \mathrm{~m}$ depth within a given year were very similar to each other. This result is explicable since this depth is well above the di- rect influence of the mound and absolute distances between successive CTD samples were small $(<1 \mathrm{~km})$. Samples on and off mound showed similar microbial compositions at $400 \mathrm{~m}$. In contrast, samples at 5 and 10 mab differed between mound summit, mound slope and (deeper) off-mound locations (Fig. 7). To explain this differentiation of the microbial communities according to mound site we infer that a gradient in environmental conditions exists on the mound. This hypothetical gradient is caused by internal waves coming from the deep and causing cold water to wash up the slope, exposing the lower part to more intense mixing, lower temperatures and different water chemistry for longer periods than the upper slope while the summit is not reached by the wave (van Haren et al., 2014).

Microbial OTU diversity was the highest in near-bottom water and decreased subsequently in sediment, skeleton, mucus and overlaying water. The enhanced microbial diversity of near-bottom water we encountered possibly reflects the enhanced biodiversity of metazoans living on the coral framework (Bongiorni et al., 2010). Similarly, Schöttner et al. (2009) found the highest microbial OTU diversity in sediments followed by overlaying seawater, and lower diversities in mucus and skeleton in a Norwegian cold-water coral reef.

Due to our method of collecting near-bottom water within the coral framework with a box corer, a certain amount of suspended sediment could be expected in the near-bottom water sample and indeed in the MDS plot (Fig. 4) the cluster of near-bottom water is situated in between the clusters of overlaying water and sediment. However, from the inventory of microbial classes present in the biotopes, it is apparent that near-bottom water supports a microbial community clearly different from a mixture of overlaying water and sediment. Moreover, near-bottom water contained a number of strong indicator taxa that were highly specific (high A values in indicspecies analyses) for this biotope, confirming its distinct signature (Table S2).

The large difference between near-bottom water and overlaying water at 5 and 10 mab was not anticipated given the strong turbulent mixing in places. We hypothesize that this difference is due to the effect of the dense 3-D coral framework constraining the exchange between the near-bottom water in between the coral branches and the water overlaying the reef. As a consequence of prolonged residence time and close contact with the dense epifauna (e.g. sponges, bivalves, foraminifera, crinoids) living in the framework and sediment, a biologically and chemically unique and sheltered environment is created for the development of a typical local microbial community with a high diversity (this study). Jensen et al. (2014) found differences between proximal and distal water samples, comparable to the differences we found between near-bottom water and overlaying water at 5 and $10 \mathrm{mab}$ : i.e. less Alphaproteobacteria and more Gammaproteobacteria and Planctomycetia in near-bottom water compared to overlaying water. However, in contrast to these findings, at a nearby reef, Jensen et al. (2014) found very similar bacte- 
A
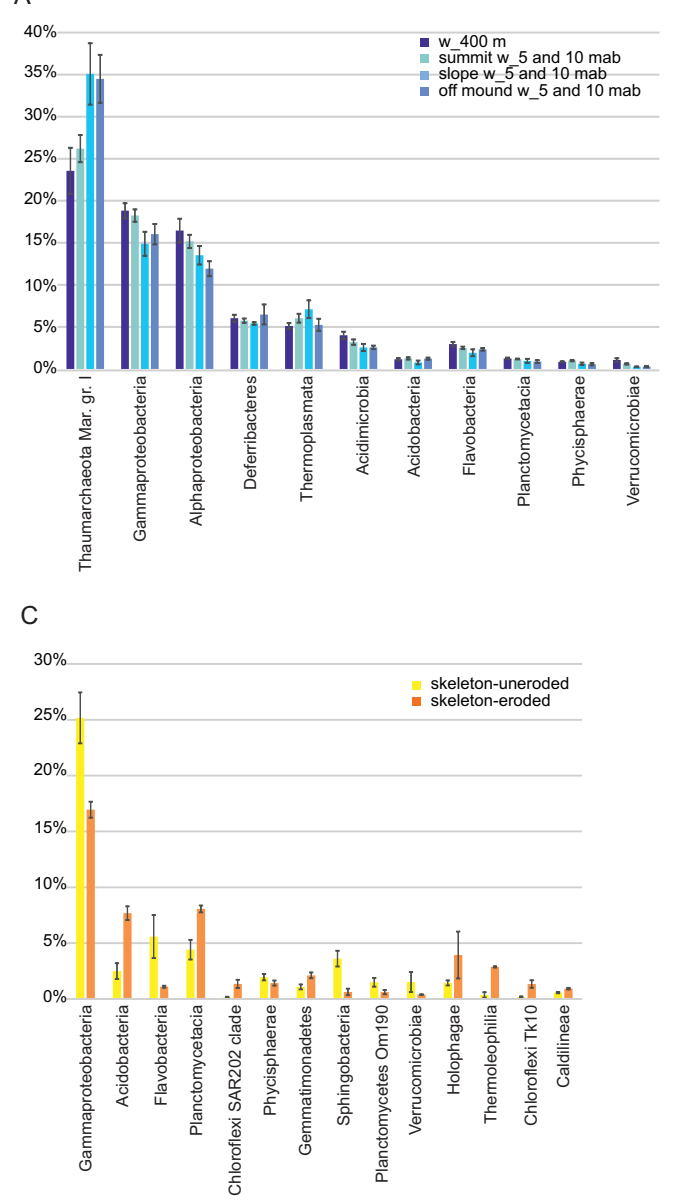

B
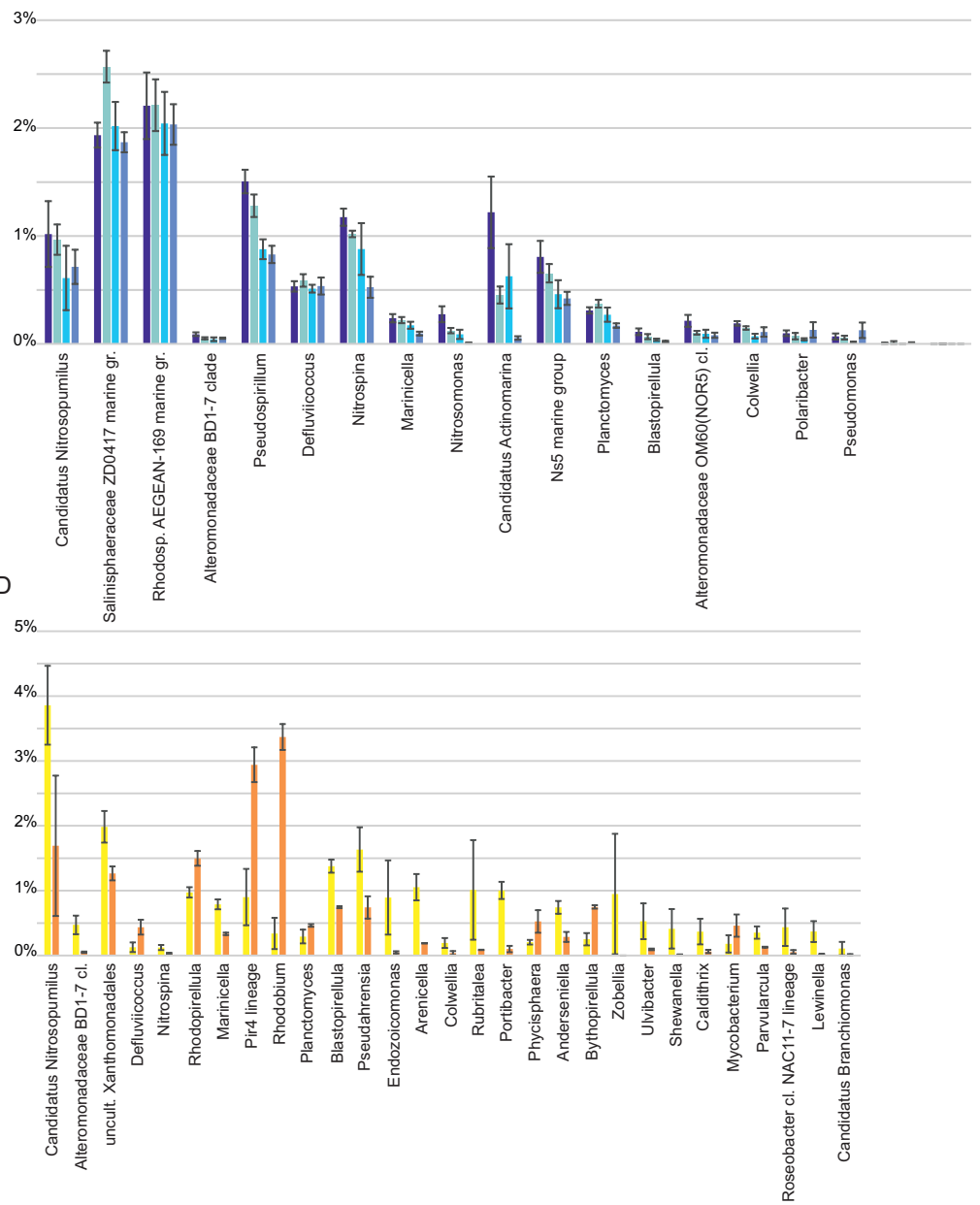

Figure 6. Differences in microbial community composition within biotopes. $N$ is the number of unique samples per biotope where the letter a shows the total number of samples, including replicates. (a) Microbial classes for overlaying water at $400 \mathrm{~m}$ depth ( $n=8$, a23), and at 5 and 10 mab on mound summit $(n=7, \mathrm{a} 21)$, mound slope $(n=4, \mathrm{a} 12)$ and off-mound $(n=4, \mathrm{a} 12)$. (b) Genera for overlaying water at $400 \mathrm{~m}$ depth, and at 5 and 10 mab on mound summit, mound slope and off-mound. (c) Microbial classes for uneroded ( $n=2$, a9) and eroded skeleton $(n=4$, a12). (d) Genera for uneroded and eroded skeleton. Values plotted as percentage with standard error.

rial OTU compositions in water collected proximal $(\sim 1 \mathrm{~m})$ and distal $(30 \mathrm{~m})$ to the reef. We anticipate that samples taken at $1 \mathrm{~m}$ above the reef will not always reflect the typical microbial community living in the coral framework depending on the hydrodynamic conditions.

\subsection{Microbial communities associated with Lophelia pertusa skeleton and mucus}

Distinct communities were identified on dead coral skeleton and in freshly produced mucus of living coral. Skeleton and mucus contained a substantial amount of Thaumarchaeota Marine Group 1 (9 and $11 \%$, respectively) of which the majority was unclassified, and the genus Nitrosopumilus made up $3 \%$ in both sample types and Cenarchaeum $0.4 \%$ in skeleton and $0.1 \%$ in mucus. In addition, small amounts of the Euryarchaeota class Halobacteria in skeleton $(0.1 \%)$ and in mucus $(0.3 \%)$, and Thermoplasmata in mucus $(0.2 \%)$ were found. It is for the first time that Archaea are detected in coral mucus. Archaea has already been reported in samples of $L$. pertusa tissue with crushed corallites (Emblem et al., 2012), and with Archaea affiliated with three species prominently present in the top 10 of prokaryotic species based on 454 read data: Nitrosopumilus maritimus, Cenarchaeum symbiosum and Candidatus Nitrosoarchaeum sp.

Although not detected by Yakimov (2006), two bacterial genera were previously reported to be part of the L. pertusa biome, Mycoplasma and TM7 (Kellogg et al., 2009; Neulinger et al., 2009; Neulinger et al., 2008). In this study, using 454 sequencing, we detected these genera in relatively low amounts: Mycoplasma was detected in skeleton $(0.028 \%)$, near-bottom water $(0.013 \%)$ and overlaying water $(0.001 \%)$, however not in mucus and sediment. Candidate division TM7 was found in all biotopes, with the highest rel- 


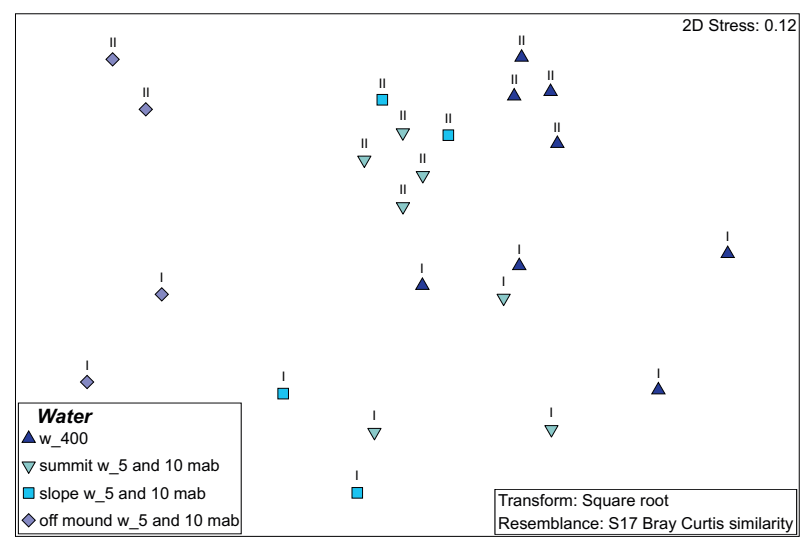

Figure 7. Zoom-in of microbial OTU composition of overlaying water (w_400 m and w_5 and $10 \mathrm{mab}$ ). Roman numeral I is 2012 and II is 2013.

ative amounts in skeleton $(0.115 \%)$ and mucus $(0.071 \%)$. With high densities of microorganisms, these small relative percentages of Mycoplasma and TM7 may still translate into significant numbers. Moreover, the percentages we report for TM7 may be severe underestimations because the primers we used have a low coverage for candidate divisions WS6, TM7 and OP11 (Klindworth et al., 2013). In our samples of freshly collected mucus, the genera Alteromonadaceae BD1-7 clade (22\%) and Acinetobacter (9\%) were highly represented, and also Endozoicomonas, Polaribacter, Pseudomonas, Aquabacterium and Thalassospira stood out in mucus. Representatives of Acinetobacter have been reported from cold-water coral (Hansson et al., 2009) and from both healthy and diseased tropical corals (Koren and Rosenberg, 2008; Luna et al., 2010; Rohwer et al., 2002). Members of this genus are well known for their resistance to numerous antibiotics (Devi et al., 2011) and may play a role in the defensive tactics of corals (Shnit-Orland and Kushmaro, 2009). Pseudomonas strains are also known for their antibacterial activity (Ye and Karn, 2015) and this genus has been found before in L. pertusa (Emblem et al., 2012) and in soft corals (Salasia and Lämmler, 2008).

Endozoicomonas contains aerobic and halophilic members reported to be associated with corals (Alsheikh-Hussain, 2011; Bayer et al., 2013; Hansson et al., 2009; Kellogg et al., 2009; Pike et al., 2013; Yang et al., 2010) and other marine invertebrates. (Kurahashi and Yokota, 2007; Nishijima et al., 2013). Recent results of Ainsworth et al. (2015) indicate that Endozoicimonaceae are likely localized to either the outer coral surface mucus layer or the coral skeleton, as they were found exclusively in the whole organism microbiome and not in isolated coral tissues. Our results confirm that both the mucus $(1.5 \%)$ and uneroded (recently deceased coral) skeleton $(0.9 \%)$ are habitats for Endozoicomonas. The Endozoicomonas found in near-bottom water $(0.2 \%)$ is probably also related to the presence of mucus. L. pertusa is able

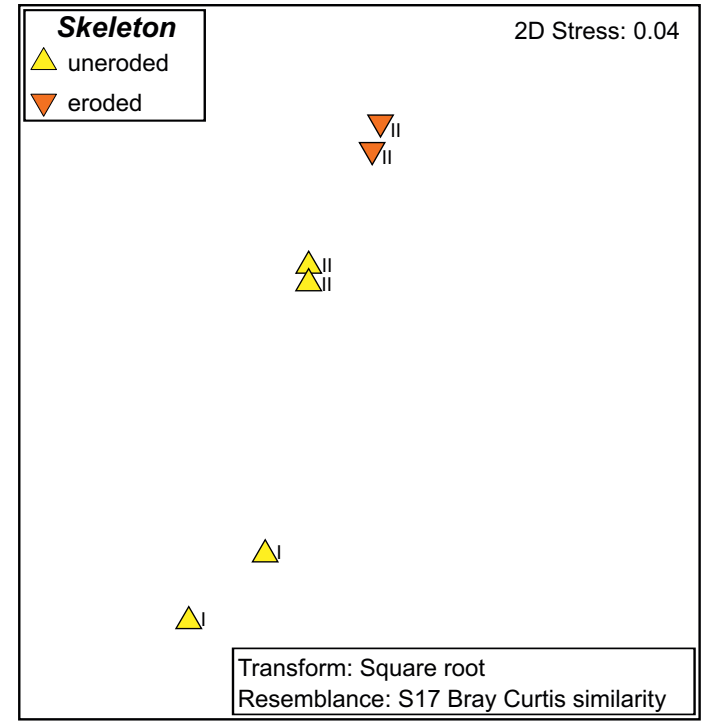

Figure 8. Zoom of microbial OTU composition of coral skeleton (eroded and uneroded). Roman capital I = 2012, II = 2013.

to produce large amounts of mucus that partly dissolve in the water and stimulated oxygen consumption and microbial activity in near-bottom water up to 10 times that of in overlaying water (Wild et al., 2008). In this sense Endozoicomonas may be an indicator for reef or framework water: the genus was not found in sediment, nor in overlaying water at 5 and $10 \mathrm{mab}$.

Different microbial communities were associated with uneroded skeleton compared to eroded skeleton. The microbial community apparently undergoes a major shift upon the death of the coral host, and continues to change as the skeleton degrades over time. This is congruent with reports on microbial succession in shallow-water tropical scleractinians that compared live tissue to recently denuded coral skeleton (Le Campion-Alsumard et al., 1995). Schöttner et al. (2009) identified distinct microbial communities on different areas along a single branch of $L$. pertusa, pointing to a cold-water coral framework forming a highly heterogeneous environment.

The variations between the different biotopes and within the biotopes that were sampled during this study emphasize that increasing understanding in the role of microbes in cold-water coral ecosystems requires both improved taxonomic resolution and actual knowledge of local biotopes, hydrography and chemical oceanography. Although our study of this single carbonate mound is among few that integrate information on hydrography with microbiology, it has for practical and logistic reasons by no means been exhaustive, and numerous pathways of future research are still open. These include further exploration of the diversity of microbial communities associated with living coral tissue, and the potential reliance of cold-water corals on their microbial as- 
sociates for chemically produced energy (Ainsworth et al., 2010; Dinsdale and Rohwer, 2011; Kellogg et al., 2009; Rohwer and Kelley, 2004). Also, interactions with chemical oceanography (e.g. nutrients, oxygen gradients) need to be explored similarly as with specific epifaunal organisms, especially sponges. Furthermore, comparisons on a somewhat larger scale between the prominent Haas Mound and nearby mounds of smaller dimensions may shed light on the specific roles of microbes in mound development.

\section{The Supplement related to this article is available online at doi:10.5194/bg-12-4483-2015-supplement.}

Acknowledgements. We would like to thank the captain and crew of the RV Pelagia and technicians of the NIOZ for their assistance during cruises 64PE360 (2012) and 64PE377 (2013), and Hans Malschaert for Linux support. This study was funded by the NIOZ Royal Netherlands Institute for Sea Research, Texel, the Netherlands, and was partially funded by the Innovational Research Incentives Scheme of the Netherlands Organization for Scientific Research (NWO VENI) awarded to FM.

Edited by: G. Herndl

\section{References}

Ainsworth, T., Krause, L., Bridge, T., Torda, G., Raina, J.-B., Zakrzewski, M., Gates, R. D., Padilla-Gamino, J. L., Spalding, H. L., Smith, C., Woolsey, E. S., Bourne, D. G., Bongaerts, P., Hoegh-Guldberg, O., and Leggat, W.: The coral core microbiome identifies rare bacterial taxa as ubiquitous endosymbionts, ISME J., 1-14, doi:10.1038/ismej.2015.39, 2015.

Ainsworth, T. D., Thurber, R. V., and Gates, R. D.: The future of coral reefs: a microbial perspective, Trends Ecol. Evol., 25, 233$240,2010$.

Alsheikh-Hussain, A.: Spatial Exploration and Characterization of Endozoicomonas spp. Bacteria in Stylophora pistillata Using Fluorescence In Situ Hybridization, King Abdullah University, Thesis, 2011.

Bayer, T., Arif, C., Ferrier-Pagès, C., Zoccola, D., Aranda, M., and Voolstra, C. R.: Bacteria of the genus Endozoicomonas dominate the microbiome of the Mediterranean gorgonian coral Eunicella cavolini, Mar. Ecol-Prog. Ser., 479, 75-84, 2013.

Biber, M. F., Duineveld, G. C. A., Lavaleye, M. S. S., Davies, A. J., Bergman, M. J. N., and van den Beld, I. M. J.: Investigating the association of fish abundance and biomass with cold-water corals in the deep Northeast Atlantic Ocean using a generalised linear modelling approach, Deep-Sea Res. Pt. II, 99, 134-145, 2014.

Bongiorni, L., Mea, M., Gambi, C., Pusceddu, A., Taviani, M., and Danovaro, R.: Deep-water scleractinian corals promote higher biodiversity in deep-sea meiofaunal assemblages along continental margins, Biol. Conserv., 143, 1687-1700, 2010.
Carlos, C., Torres, T. T., and Ottoboni, L. M. M.: Bacterial communities and species-specific associations with the mucus of Brazilian coral species, Scientific Reports, 3, 1-7, doi:10.1038/srep01624, 2013.

Claesson, M. J., O’Sullivan, O., Wang, Q., Nikkilä, J., Marchesi, J. R., Smidt, H., de Vos, W. M., Ross, R. P., and O'Toole, P. W.: Comparative analysis of pyrosequencing and a phylogenetic microarray for exploring microbial community structures in the human distal intestine, PloS one, 4, 1-15, doi:10.1371/journal.pone.00066699, 2009.

Clarke, K. and PRIMER, G. R.: V6: user manual/tutorial, Primer-E Ltd. Plymouth, 2006.

Clarke, K. R.: Non-parametric multivariate analyses of changes in community structure., Austral. J. Ecol., 18, 117-143, 1993.

Clarke, K. R. and Gorley, R. N.: Primer v6: user manual/tutorial, Plymouth, 190 pp., 2006.

Cole, J. R., Wang, Q., Fish, J. A., Chai, B., McGarrell, D. M., Sun, Y., Brown, C. T., Porras-Alfaro, A., Kuske, C. R., and Tiedje, J. M.: Ribosomal Database Project: data and tools for high throughput rRNA analysis, Nucleic Acids Res., 42, D633-D642, 2014.

Costello, M. J., McCrea, M., Freiwald, A., Lundälv, T., Jonsson, L., Bett, B. J., van Weering, T. C., de Haas, H., Roberts, J. M., and Allen, D.: Role of cold-water Lophelia pertusa coral reefs as fish habitat in the NE Atlantic. In: Cold-water corals and ecosystems, Springer, Heidelberg, Germany, 771-805, 2005.

De Caceres, M. and Legendre, P.: Associations between species and groups of sites: indices and statistical inference, Ecology, 90, 3566-3574, 2009.

De Haas, H., Mienis, F., Frank, N., Richter, T. O., Steinacher, R., De Stigter, H., Van der Land, C., and Van Weering, T. C.: Morphology and sedimentology of (clustered) cold-water coral mounds at the south Rockall Trough margins, NE Atlantic Ocean, Facies, 55, 1-26, 2009.

Devi, P., Wahidulla, S., Kamat, T., and D'Souza, L.: Screening marine organisms for antimicrobial activity against clinical pathogens, Indian J. Mar. Sci., 40, 338-346, 2011.

Dinsdale, E. A. and Rohwer, F.: Fish or germs? Microbial dynamics associated with changing trophic structures on coral reefs, in: Coral Reefs: An Ecosystem in Transition, Springer, Heidelberg, Germany, 231-240, 2011.

Dufrene, M. and Legendre, P.: Species assemblages and indicator species: The need for a flexible asymmetrical approach, Ecol. Monogr., 67, 345-366, 1997.

Duineveld, G. C., Lavaleye, M. S., Bergman, M. J., De Stigter, H., and Mienis, F.: Trophic structure of a cold-water coral mound community (Rockall Bank, NE Atlantic) in relation to the nearbottom particle supply and current regime, B. Mar. Sci., 81, 449467, 2007.

Emblem, A., Karlsen, B. O., Evertsen, J., Miller, D. J., Moum, T., and Johansen, S. D.: Mitogenome polymorphism in a single branch sample revealed by SOLiD deep sequencing of the Lophelia pertusa coral genome, Gene, 506, 344-349, 2012.

Findlay, H. S., Hennige, S. J., Wicks, L. C., Navas, J. M., Woodward, E. M. S., and Roberts, J. M.: Fine-scale nutrient and carbonate system dynamics around cold-water coral reefs in the northeast Atlantic, Scientific reports, 4, 1-10, doi:10.1038/srep03671, 2014.

Galkiewicz, J. P., Pratte, Z. A., Gray, M. A., and Kellogg, C. A.: Characterization of culturable bacteria isolated from the cold- 
water coral Lophelia pertusa, FEMS Microbiol. Ecol., 77, 333346, 2011.

Genin, A., Yahel, G., Reidenbach, M. A., Monismith, S. B., and Koseff, J. R.: Intense benthic grazing on phytoplankton in coral reefs revealed using the control volume approach, Oceanography, 15, 90-96, 2002.

Gilbert, J. A., Hill, R., Doblin, M. A., and Ralph, P. J.: Microbial consortia increase thermal tolerance of corals, Mar. Biol., 159, 1763-1771, 2012.

Hansson, L., Agis, M., Maier, C., and Weinbauer, M. G.: Community composition of bacteria associated with cold-water coral Madrepora oculata: within and between colony variability, Mar. Ecol.-Prog. Ser., 397, 89-102, 2009.

Henry, L.-A. and Roberts, J. M.: Biodiversity and ecological composition of macrobenthos on cold-water coral mounds and adjacent off-mound habitat in the bathyal Porcupine Seabight, NE Atlantic, Deep-Sea Res. Pt. I, 54, 654-672, 2007.

Jensen, S., Bourne, D. G., Hovland, M., and Murrell, J. C.: High diversity of microplankton surrounds deep-water coral reef in the Norwegian Sea, FEMS Microbiol. Ecol., 82, 75-89, 2012.

Jensen, S., Lynch, M. D. J., Ray, J. L., Neufeld, J. D., and Hovland, M.: Norwegian deep-water coral reefs: cultivation and molecular analysis of planktonic microbial communities, Environ. Microbiol., doi:10.1111/1462-2920.12531, 2014.

Jensen, S., Neufeld, J. D., Birkeland, N.-K., Hovland, M., and Murrell, J. C.: Insight into the microbial community structure of a Norwegian deep-water coral reef environment, Deep-Sea Res. Pt. I, 55, 1554-1563, 2008.

Kellogg, C. A., Lisle, J. T., and Galkiewicz, J. P.: Cultureindependent characterization of bacterial communities associated with the cold-water coral Lophelia pertusa in the northeastern Gulf of Mexico, Appl. Environ. Microb., 75, 2294-2303, 2009.

Kenyon, N. H., Akhmetzhanov, A. M., Wheeler, A. J., van Weering, T. C., de Haas, H., and Ivanov, M. K.: Giant carbonate mud mounds in the southern Rockall Trough, Mar. Geol., 195, 5-30, 2003.

Klindworth, A., Pruesse, E., Schweer, T., Peplies, J., Quast, C., Horn, M., and Glöckner, F. O.: Evaluation of general 16S ribosomal RNA gene PCR primers for classical and next-generation sequencing-based diversity studies, Nucleic Acids Res., 41, e1e1, 2013.

Knowlton, N. and Rohwer, F.: Multispecies microbial mutualisms on coral reefs: the host as a habitat, Am. Nat., 162, S51-S62, 2003.

Koren, O. and Rosenberg, E.: Bacteria associated with the bleached and cave coral Oculina patagonica, Microbial Ecol., 55, 523529, 2008

Krediet, C. J., Ritchie, K. B., Alagely, A., and Teplitski, M.: Members of native coral microbiota inhibit glycosidases and thwart colonization of coral mucus by an opportunistic pathogen, ISME J., 7, 980-990, 2013.

Kurahashi, M. and Yokota, A.: Endozoicomonas elysicola gen. nov., sp nov., a gamma-proteobacterium isolated from the sea slug Elysia ornata, Syst. Appl. Microbiol., 30, 202-206, 2007.

Le Campion-Alsumard, T., Golubic, S., and Hutchings, P.: Microbial endoliths in skeletons of live and dead corals - Porites lobata (Moorea, French-Polynesia), Mar. Ecol.-Progr. Ser., 117, 149157, 1995.
Luna, G. M., Bongiorni, L., Gili, C., Biavasco, F., and Danovaro, R.: Vibrio harveyi as a causative agent of the White Syndrome in tropical stony corals, Environ. Microbiol., 2, 120-127, 2010.

McGrath, T., Nolan, G., and McGovern, E.: Chemical characteristics of water masses in the Rockall Trough, Deep-Sea Res. Pt. I, 61, 57-73, 2012.

Mienis, F., Van Weering, T., De Haas, H., De Stigter, H., Huvenne, V., and Wheeler, A.: Carbonate mound development at the SW Rockall Trough margin based on high resolution TOBI and seismic recording, Mar. Geol., 233, 1-19, 2006.

Mienis, F., De Stigter, H. C., White, M., Duineveld, G., De Haas, H., and Van Weering, T. C. E.: Hydrodynamic controls on cold-water coral growth and carbonate-mound development at the SW and SE Rockall Trough Margin, NE Atlantic Ocean, Deep-Sea Res. Pt. I, 54, 1655-1674, 2007.

Mohn, C., Rengstorf, A., White, M., Duineveld, G., Mienis, F., Soetaert, K., and Grehan, A.: Linking benthic hydrodynamics and cold-water coral occurrences: A high-resolution model study at three cold-water coral provinces in the NE Atlantic, Progr. Oceanogr., 122, 92-104, 2014.

Neulinger, S. C., Järnegren, J., Ludvigsen, M., Lochte, K., and Dullo, W.-C.: Phenotype-specific bacterial communities in the cold-water coral Lophelia pertusa (Scleractinia) and their implications for the coral's nutrition, health, and distribution, Appl. Environ. Microbiol., 74, 7272-7285, 2008.

Neulinger, S. C., Gaertner, A., Jarnegren, J., Ludvigsen, M., Lochte, K., and Dullo, W.-C.: Tissue-Associated "Candidatus Mycoplasma corallicola" and Filamentous Bacteria on the ColdWater Coral Lophelia pertusa (Scleractinia), Appl. Enviro. Microbiol., 75, 1437-1444, 2009.

Nishijima, M., Adachi, K., Katsuta, A., Shizuri, Y., and Yamasato, K.: Endozoicomonas numazuensis sp. nov., a gammaproteobacterium isolated from marine sponges, and emended description of the genus Endozoicomonas Kurahashi and Yokota 2007, Int. J. Syst. Evol. Micr., 63, 709-714, 2013.

Penn, K., Wu, D., Eisen, J. A., and Ward, N.: Characterization of bacterial communities associated with deep-sea corals on Gulf of Alaska seamounts, Appl. Envir. Microbiol., 72, 1680-1683, 2006.

Pike, R. E., Haltli, B., and Kerr, R. G.: Endozoicomonas euniceicola sp. nov. and Endozoicomonas gorgoniicola sp. nov., bacteria isolated from the octocorals, Eunicea fusca and Plexaura sp, Int. J. Syst. Evol. Micr., 63, 4294-4302, 2013.

Reidenbach, M. A., Monismith, S. G., Koseff, J. R., Yahel, G., and Genin, A.: Boundary layer turbulence and flow structure over a fringing coral reef, Limnol. Oceanogr., 51, 1956-1968, 2006.

Rohwer, F. and Kelley, S.: Culture-independent analyses of coralassociated microbes. In: Coral health and disease, Springer, Heidelberg, Germany, 265-277, 2004.

Rohwer, F., Seguritan, V., Azam, F., and Knowlton, N.: Diversity and distribution of coral-associated bacteria, Mar. Ecol.-Progr. Ser., 243, 1-10, 2002.

Rosenberg, E., Kellogg, C. A., and Rohwer, F.: Coral microbiology, Washington, 146 pp., 2007.

Rovelli, L., Attard, K. M., Bryant, L. D., Floegel, S., Stahl, H., Roberts, J. M., Linke, P., and Glud, R. N.: Benthic $\mathrm{O}_{2}$ uptake of two cold-water coral communities estimated with the noninvasive eddy correlation technique, Mar. Ecol.-Progr. Ser., 525, 97-104, 2015. 
Salasia, S. and Lämmler, C.: Antibacterial property of marine Bacterium pseudomonas $\mathrm{sp}$. associated with a soft coral against pathogenic Streptococcus equi subsp, zooepidemicus, J. Coastal Developm., 11, 113-120, 2008.

Schöttner, S., Hoffmann, F., Wild, C., Rapp, H. T., Boetius, A., and Ramette, A.: Inter-and intra-habitat bacterial diversity associated with cold-water corals, ISME J., 3, 756-759, 2009.

Schöttner, S., Wild, C., Hoffmann, F., Boetius, A., and Ramette, A.: Spatial scales of bacterial diversity in cold-water coral reef ecosystems, PloS one, 7, e32093, doi:10.1371/journal.pone.0032093, 2012.

Shnit-Orland, M. and Kushmaro, A.: Coral mucus-associated bacteria: a possible first line of defense, FEMS Microbiol. Ecol., 67, 371-380, 2009.

Templer, S. P., Wehrmann, L. M., Zhang, Y., Vasconcelos, C., and McKenzie, J. A.: Microbial community composition and biogeochemical processes in cold-water coral carbonate mounds in the Gulf of Cadiz, on the Moroccan margin, Mar. Geo., 282, 138148, 2011.

van Haren, H., Mienis, F., Duineveld, G. C., and Lavaleye, M. S.: High-resolution temperature observations of a trapped nonlinear diurnal tide influencing cold-water corals on the Logachev mounds, Progr. Oceanogr., 125, 16-25, 2014.

van Oevelen, D., Duineveld, G., Lavaleye, M., Mienis, F., Soetaert, K., and Heip, C. H.: The cold-water coral community as a hot spot for carbon cycling on continental margins: A food-web analysis from Rockall Bank (northeast Atlantic), Limnol. Oceanogr., 54, 1829-1844, 2009.

van Soest, R. W., Cleary, D. F., de Kluijver, M. J., Lavaleye, M. S., Maier, C., and van Duyl, F. C.: Sponge diversity and community composition in Irish bathyal coral reefs, Contrib. Zool., 76, 121$142,2008$. van Weering, T. C., De Haas, H., De Stigter, H., Lykke-Andersen, H., and Kouvaev, I.: Structure and development of giant carbonate mounds at the SW and SE Rockall Trough margins, NE Atlantic Ocean, Mar. Geol., 198, 67-81, 2003.

Wang, Q., Garrity, G. M., Tiedje, J. M., and Cole, J. R.: Naive Bayesian classifier for rapid assignment of rRNA sequences into the new bacterial taxonomy, Appl. Environ. Microbiol., 73, 5261-5267, 2007.

Wild, C., Mayr, C., Wehrmann, L., Schöttner, S., Naumann, M., Hoffmann, F., and Rapp, H. T.: Organic matter release by cold water corals and its implication for fauna-microbe interaction, Mar. Ecol.-Prog. Ser., 372, 67-75, 2008.

Yakimov, M. M., Cappello, S., Crisafi, E., Tursi, A., Savini, A., Corselli, C., Scarfi, S., and Giuliano, L.: Phylogenetic survey of metabolically active microbial communities associated with the deep-sea coral Lophelia pertusa from the Apulian plateau, Central Mediterranean Sea, Deep-Sea Res. Pt. I, 53, 62-75, 2006.

Yang, C.-S., Chen, M.-H., Arun, A., Chen, C. A., Wang, J.-T., and Chen, W.-M.: Endozoicomonas montiporae sp. nov., isolated from the encrusting pore coral Montipora aequituberculata, Int J. Syst. Evol. Micr., 60, 1158-1162, 2010.

Ye, F. and Karn, J.: Bacterial Short Chain Fatty Acids Push All The Buttons Needed To Reactivate Latent Viruses, Stem Cell Epigen., 2, 1-3, 2015.

Yilmaz, N., Visagie, C. M., Houbraken, J., Frisvad, J. C., and Samson, R. A.: Polyphasic taxonomy of the genus Talaromyces, Studies in Mycology, 78, 175-341, 2014. 